\title{
The dynamics of job creation and job destruction in Australia
}

William Mitchell, James Juniper and Jenny Myers

\section{Abstract}

This paper develops measures of job creation and job destruction (JC\&D) based on the methodology initially developed by Davis and Haltiwanger (1990) and using industry employment data from the ABS Survey of Employment and Earnings (SEE), which is available on a quarterly basis between August 1983 and December 2001. It specifically examines the interaction of part-time and full-time employment with JC\&D processes over the business cycle: Econometric analysis has been conducted to determine the time series properties of cyclical sensitivity and asymmetry. These findings are considered in the context of the likely consequences of the Howard government's Work Choices legislation.

Keywords: Employment dynamics, casual employment, recession 


\section{Introduction}

Several studies reveal that labour markets in countries like Australia are in a constant state of flux (for example, U.S. studies by Blanchard and Diamond, 1990; Davis and Haltiwanger, 1990, 1992; Ritter, 1993, 1994; Davis, Haltiwanger and Schuh, 1996; U.K. studies by Konings, 1995; Blanchflower and Burgess, 1996; and Australian work by Borland, 1996; Mumford and Smith, 2003). Specific jobs are continually created and destroyed as firms expand, adjust to changing labour force characteristics, restructure, contract or close. This process of job creation and destruction (JC\&D) is mirrored by movements of workers between labour force states. Analysis of employment dynamics using macroeconomic data typically focuses on measures of net employment changes over time. However, this aggregate focus prevents an understanding of flows noted above (numbers of jobs created and destroyed and movements of workers across labour force categories).

This paper is the first in a series, which explores the cyclical nature and determinants of job dynamics in Australia, and concentrates on two views of these dynamic processes: (a) employment flows by broad industry sector (goods production; wholesale and retail; and other services); and (b) employment flows by full- and part-time status.

Most authors to date use manufacturing data to compute measures of JC\&D to study their evolution across the business cycle. The U.S. evidence indicates that gross job flows are both highly cyclical and asymmetric. Job destruction increases sharply during recessions, while job creation is less volatile and varies both counter- and pro-cyclically (Davis and Haltiwanger, 1992). Borland's (1996) Australian study focuses on job creation and job destruction in Manufacturing. Borland finds that JC\&D occurs simultaneously in disaggregated sectors. Moreover, those sectors experiencing high rates of job creation also have higher rates of job destruction. Job creation varies pro-cyclically with changes in net employment while job destruction varies counter-cyclically, with the latter marked by relatively greater cyclical sensitivity. The persistence of JC\&D also displays strong cyclical patterns (see Mitchell, 2001).

However, with manufacturing employment declining in absolute and relative importance and most new jobs being created in the service sector, it is important to pitch a study at the sectoral level so that economy-wide trends can be decomposed to reveal what might otherwise be offsetting processes of JC\&D occurring within individual industries. Ritter (1994) shows the benefits of industry disaggregation for the US. He concludes that patterns within manufacturing and other goods-producing industries contribute disproportionately to changes in overall JC\&D, especially during recessions. Moreover, cyclical asymmetries between JC\&D in the goods-producing sector do not carry over to other sectors. Finally, he observes that job creation and job destruction fell notably during the early 1990 s recession in the US.

A further consideration, not reflected in previous work, relates to the dramatic changes labour markets have undergone over the last 25 years (see Mitchell et al., 2005a). In Australia, part-time jobs now constitute the majority of new (net) employment, while full-time job opportunities declined substantially over the 1990s (although 1,009.8 thousand full-time jobs and 668.6 thousand part-time jobs were created between December 1979 and December 1989, in the following decade the net change in full-time 
employment amounted to 388.4 thousand with 668.9 thousand part-time jobs created net, a process that continued apace over the next five years). This trend towards increasingly fractionalised employment has eroded career opportunities for increasing numbers of Australian workers (see Mitchell et al., 2005a), creating a dualistic labour market structure (Debelle and Swan, 1998; Song and Webster, 2003). The quality of the work experience has also deteriorated given the characteristics of many part-time 'non-standard' jobs - precarious tenure, low pay, non-standard working hours (Borland et al., 2001).

We aim to investigate whether the relative increase in the importance of part-time work has changed the processes of JC\&D. To this end we exploit survey data on employment, which extends from 1983 to 2001, thus including two recessions. The data also allows for decompositions of sectoral rates of job creation and destruction into both part-time and full-time employment. We reveal that it is this differential responsiveness of part-time and full-time employment to the movement of GDP over the business cycle - the sensitivity is captured by measures of asymmetry and persistence - which dominates as an influence over both sectoral and aggregate patterns of job creation and destruction.

The paper is organised as follows. Section 2 defines the gross job flow measures to be used. Section 3 examines the behaviour of full-time and part-time employment over the business cycle as motivation for the more detailed sectoral breakdown in Section 4 and full- and part-time analysis in Section 5. Stylised facts are presented in both Sections 4 and 5 and regressions exploring the cyclical sensitivity of job creation and destruction are reported. Section 6 considers the results in the context of the WorkChoices legislation that has radically recast the industrial relations terrain in Australia. Concluding remarks follow.

\section{Data issues and gross labour flow measures}

\subsection{Data sources}

We use the ABS Survey of Employment and Earnings (SEE), which provides quarterly industry employment data from August 1983 to December 2001 for 2-digit industry and full-time/part-time status. The SEE data offers some advantages over other establishment data (such as the manufacturing survey used in Borland, 1996) because it is quarterly so that the netting out problem, which arises when dynamic behaviour hidden by net changes, is less severe relative to annual data. Moreover, the longer time series spans two clear business cycles permitting the analysis of the cyclical variations in job flow.

We use the 2-digit level data to group industry employment into three broad sectors (see Ritter, 1994): (a) a goods-producing sector (G) comprising Manufacturing, Construction and Mining; (b) a wholesale and retail trade sector ( $T$ ); and (c) an other services sector (R) comprising Transport; Electricity, Gas and Water; Communications; Finance and Insurance; Property and Business Services; Accommodation, Café and Restaurants; Education; Cultural and Recreational Services; and Personal and Other Services (excluding Private households employing staff which was unavailable). 


\subsection{Measuring gross job creation and destruction}

The analysis in this paper is based on the widely used job creation rate (JCR) and job destruction rate $(J D R)$ measures introduced by Davis and Haltiwanger $(1990,1992)$. Davis and Haltiwanger (1992: 827-8) calculate "gross job creation by summing the employment gains at expanding and new establishments within a sector. Similarly, we calculate gross job destruction by summing employment losses at shrinking and dying establishments within a sector." These job flows are converted to rates by dividing by the 'size' (being the average employment in that industry for the current and previous periods). These calculations are undertaken for each 2-digit industry. The gross job creation (destruction) rates for the three broad-sectors are the summation of job creation (destruction) rates for each industry within that sector, weighted by the proportion of that industry's size to the broad-sector size.

Rates of job reallocation (JRA) are the summation of JCR and JDR, while net employment growth (NET) is the difference between JCR and JDR (see Mitchell et al., 2005b for a more detailed description of measures, data anomalies and data amendments).

\section{Cyclical swings in full-time and part-time employment}

By way of motivation, Figure 1 depicts 'butterfly' plots which trace movements in full-time and part-time employment in Australia for males and females over the 1982 and 1991 recessions. The plots begin 4-quarters before the peaks in GDP activity, then trace the behaviour from peak to trough and then 8-quarters following the trough (dating is explained in Mitchell, 2001). The shaded areas indicate the period between peak and trough in each cycle. The employment series are index numbers with the base coinciding with the peak GDP quarter.

Several points are worth noting. First, during recessions a marked switch from full-time work to part-time work for both males and females occurs resulting in a greater proportion of workers in short-duration jobs. This is accentuated for males. In the period immediately prior to each of the two peaks the full-time/part-time ratio is relatively stable for males and females. During the recession and subsequent recovery, the ratio rises rapidly before stabilising at the higher level with the underlying trend towards increased part-time work then reasserting itself.

Second, male employment adjustments begin with part-time work increasing rapidly in the last quarter of the expansion and accompanied by a slowing, then substantial decline in full-time employment. The pattern is repeated in the 1991 recession. For females, the slowdown in part-time employment growth in late 1981 leads the decline in full-time work. Both pre-date the contraction.

Third, full-time employment declines almost lockstep with the turn in GDP and persists before weak recovery begins. Part-time work, however, continues to increase as GDP moves from peak to trough, until it also succumbs to the effects of demand deficiency. In the recovery phase, the economy initially generates strong growth in part-time work.

Fourth, although recessions have been likened to 'taking a pitstop' so that managers can streamline business processes, declining productivity during recessions seems to 
contradict this interpretation (Perry, 1990). Employment also recovers very slowly following the trough. Perry (1990: 153) says that "If the amount of job creation and destruction is relatively constant in the temporary jobs, then the destruction is taking place in the long-duration jobs. This view provides a harsher picture of what happens during a recession than one would get if the change in job composition were ignored."

Figure 1: Full-time and part-time employment for males and females over 3 recessions

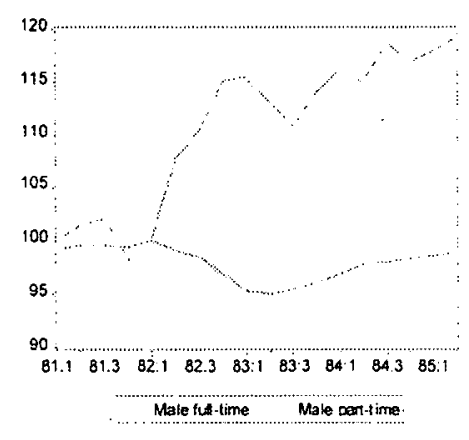

(a) Males 1981:1 to $1985: 2$

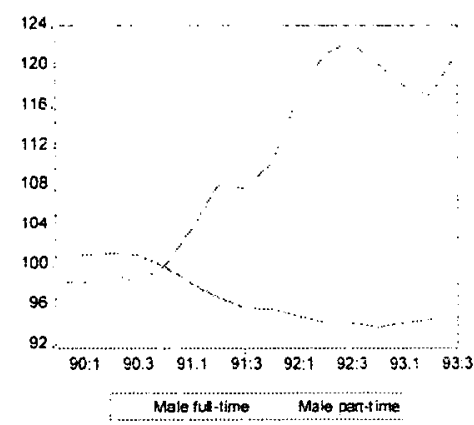

(c) Males 1989:4 1993:3

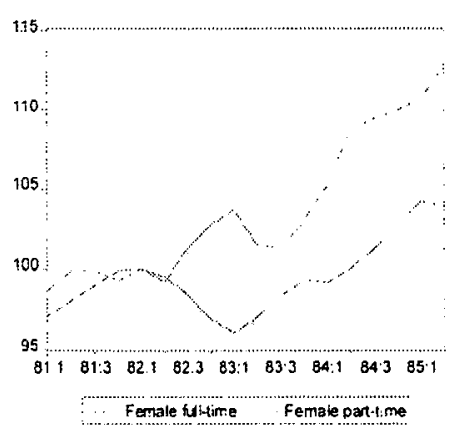

(b) Females $1981: 1$ to $1985: 2$

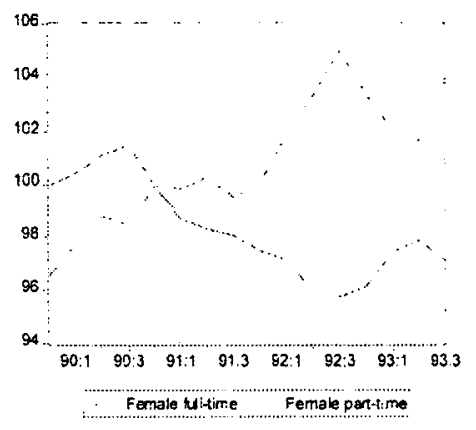

(d) Females 1989:4 1993:3

Note: see Mitchell (2001) for an explanation of the shaded areas.

\section{Sectoral job dynamics - is manufacturing representative?}

Using these findings as motivation, we now seek to more fully understand the dynamics of JC\&D at the sectoral level.

\subsection{Job creation and destruction by sector - graphical evidence}

Ritter (1993) found that manufacturing job flows dominate the counter-cyclical nature of job reallocation in the U.S. To examine whether there are sectoral differences in gross job flows across broad sectors in Australia, we aggregated 2-digit industry employment data into three broad sectors (goods-producing, wholesale and retail trade and the remaining services) to compute the $J C R$ and $J D R$ measures. We seek to determine whether the growing importance of service sector employment has altered the nature of employment flows. The demarcation has economic meaning because wholesale and 
retail trade is likely to be more closely related to goods-production (via inventory cycles) than other services and exhibit gross flow dynamics similar to manufacturing.

Figure 2 (panel a) shows the All Industries JCR and JDR measures from 1983 to 2001 (included the shaded 1991 recession). Job creation dominated the 1980 s growth period although it began falling long before GDP peaked (start of shading). The JDR rose sharply during the recession and continued rising throughout the trough. However, consistent with the evidence in Figure 1 , the JCR began its recovery mid-recession.

Figure 2: Job creation and destruction rates, various industry sectors, 1983-2001

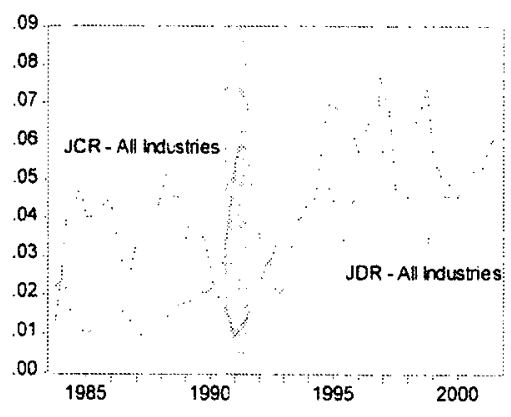

(a) JCR and JDR, All Industries

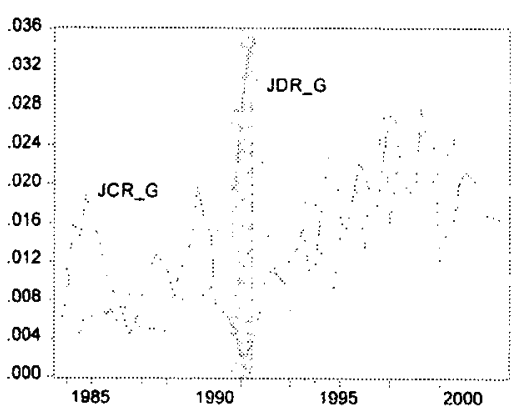

(c) Goods producing sector $(G)$

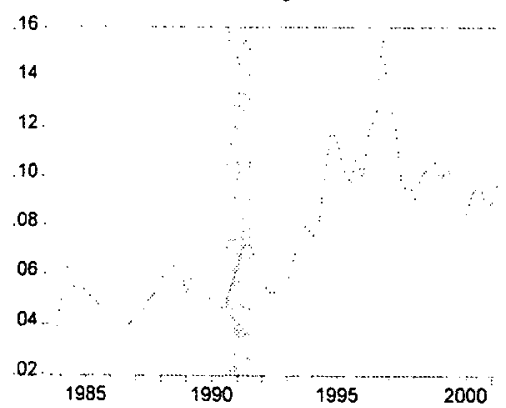

(b) Job reallocation rate, All Industries

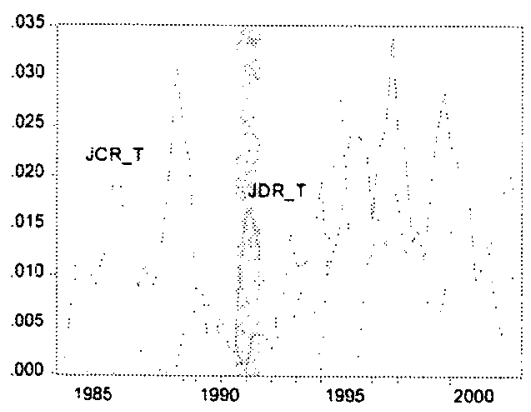

(d) Wholesale and Retail sector (T)

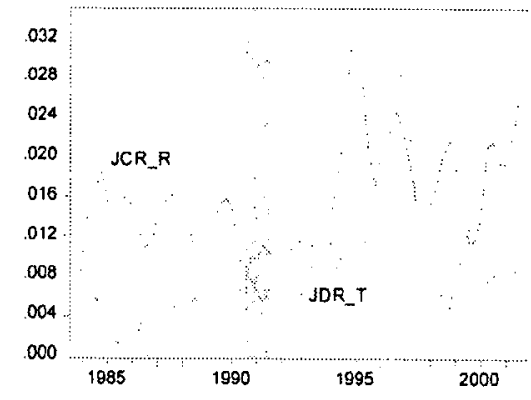

(e) Other services sector (R) 
In the 1990s growth period, job flows from both sources are higher reflecting the relative increase in part-time (and casualised) work (more transitory jobs created). Panels (c) to (e) shows the three-month centred moving averages of the JCR and JDR for the three industry groupings: goods production $(\mathrm{G})$; wholesale and retail $(T)$; and other services (R). Ritter (1994) found that job flow rates were far more volatile in the $G$ sector than in the $T$ and $R$ sectors. This finding is confirmed for Australia. For this sector the JCR and JDRs move in marked opposition to one another. Moreover, where job destruction peaked during the early 1990 s recession, job creation plummeted to new lows. This volatility and the employment share of the sector combine to explain the disproportionate contribution it has made to fluctuations in aggregate gross flows. While similar movements can be observed in other sectors, here job creation is clearly in the ascendancy, and the net job loss over the recessionary period is less pronounced.

Ritter (1994) also found that goods production accounted for more of the cyclical changes in overall JC\&D. Further decomposition of the $\mathrm{G}$ sector showed that the manufacturing sector was responsible for most of this volatility (Ritter, 1994, Graph 7: 11). This behaviour is reproduced for the Australian SEE data (see Mitchell et al., 2005b).

\subsection{Average rates of job creation and destruction by sector}

Job creation and destruction rates for the three industry sectors and total economy were broken down into the 1980s growth period up to the GDP peak in June 1990; the peak to trough in GDP corresponding to the recession; the post-1991 recession, growth period; and the full sample (see Mitchell et al., 2005b for actual measures).

Several features are worth noting. First, from 1984 to 2001, the average rate of job creation overall was 4.3 per cent while the average job destruction rate was 3.1 per cent. In the 1980 s period, the average rate of job creation overall was 3.6 per cent while the average job destruction rate was 1.4 per cent. While average job destruction rates were relatively higher than were job creation rates in the 1990 s compared to 1980 s, it is clear that the rate of job reallocation was also comparatively higher in all sectors over this period. Second, the goods sector has around twice the job destruction rate of the other sectors but about the same average job creation rate. Similar patterns prevailed in both the 1980s and 1990s. Third, while there is no evidence that the job creation rates have a higher variation than the job destruction rates across the sectors overall, they tended to be more variable in the 1990 s than in the $1980 \mathrm{~s}$. Fourth, the recession stands out as a period where average job destruction rates increased substantially, albeit mostly in the goods sector and job creation rates fell substantially across all sectors. Finally, job destruction dominates the recession period employment flows and has increased in importance over the 1990s.

The additional points of interest are, first, that rates of JC\&D are much larger than net employment growth, especially in the goods sector. Second, although the job creation rate is positively related to net employment growth in all sectors (which in turn is strongly negatively related to the job destruction rate in all sectors), the job destruction rate is positively correlated to the job destruction rate in Retail and Total but negarively related in the Goods and Trade sectors. 


\subsection{Cyclical sensitivity of job creation and job destruction rates by sector}

Borland (1996) found positive correlation between JC\&D across sectors. He also found "The rate of job destruction is negatively related to net employment growth, and the rate of job creation is weakly positively related to net employment growth" (Borland, 1996: 52).

From Figure 2, it is clear that the amplitude of the fluctuations in the series varies over time especially during recession. In this section we examine the cyclical sensitivity of the JC\&D rates more closely using regression analysis. The strength of the demand side of the economy is captured by the annualised (detrended) rate of growth of real GDP. To test for asymmetrical reactions to the business cycle we create two dummy variables by segmenting GDP growth into its positive and negative observations. We also define a recession dummy taking the value of unity between 1990:3 and 1991:3 and zero otherwise. The inclusion of this variable is intended to highlight whether the 1991 recession had an additional impact on the gross job flows.

We specifically wish to examine: (a) whether there are differences in cyclical job creation and destruction behaviour across the industrial sectors; (b) whether there is evidence of cyclical asymmetry between job creation and job destruction in the goods-producing sector and whether it carries over to other sectors; and (b) whether job creation and job destruction were dampened during the early 1990s recession (see Ritter, 1994).

The regression results are shown in Table 1 for All Industries with results for the Goods, Retail, and Trade sectors shown in Mitchell et al. (2005b). We summarise the main results only. Analysis of the disaggregated sectors suggests that job creation is more sensitive to real GDP growth than job destruction. However, when tested for asymmetry, more precision emerges. Job creation is clearly asymmetric over the business cycle and is significantly affected, other things equal, by the 1991 recession. Job destruction does not react to positive GDP growth in any significant way but rises sharply when GDP growth is negative. The recession also impacted significantly on job destruction.

Table 1: Cyclical sensitivity of job creation and destruction, All Industries, 1983:3 to 2001:4

\begin{tabular}{lcccc}
\hline Variable & $\begin{array}{c}\text { JCR_Total } \\
\text { (1) }\end{array}$ & $\begin{array}{c}\text { JCR_Total } \\
(2)\end{array}$ & $\begin{array}{c}\text { JDR_Total } \\
(3)\end{array}$ & $\begin{array}{c}\text { JDR_Total } \\
\text { (4) }\end{array}$ \\
\hline GDP growth (annualised) & $0.404(4.84)$ & & $-0.035(0.33)$ & \\
GDP growth positive & & $0.397(4.68)$ & & $0.024(0.26)$ \\
GDP growth negative & & $0.714(2.07)$ & & $-2.492(4.49)$ \\
1991 Recession & $-0.014(3.12)$ & $-0.013(3.13)$ & $0.001(7.24)$ & $0.001(7.52)$ \\
& & & & \\
Adjusted Ros & 0.611 & 0.606 & 0.665 & 0.694 \\
Std Err \% Mean Dep Var & 22.9 & 23.1 & 29.8 & 28.5 \\
No of Observations & 69 & 69 & 69 & 69 \\
\hline
\end{tabular}

Note: Detrended 3-qtr centred moving average GDP growth is used throughout. The 1991 recession took value 1 from 1990:3 to 1991:3 and zero otherwise. t-statistics in parentheses. Constant and trend terms not reported. 
Job creation in all sectors is significantly pro-cyclical although the $G$ sector has a stronger response. The All Industry regression cannot pick up the cyclical sensitivity of job destruction. However, the asymmetric regressions reveal more interesting results. Job creation in the $G$ and $R$ sectors exhibits strong asymmetric behaviour being more responsive (negatively) to GDP decline than to GDP growth. Conversely, the T sector is more responsive to positive than to negative GDP growth. However, the 1991 recession is a strongly independent negative factor for job creation in all sectors. Negative GDP growth increases job destruction, with the $G$ sector responding more strongly than the other sectors. The 1991 recession only worsens job destruction in the $G$ and T sectors.

\section{Full-time and part-time job creation and destruction by sector}

\subsection{Stylised facts of full- and part-time job creation and destruction}

Full-time and part-time rates of JC\&D were calculated for all-industries and each sector, for the entire sample as well as before, during and after the recession (refer to Mitchell et al., 2005b for values and analysis). Several features are worth noting. First, from 1984 to 2001, the average rate of job creation overall was 4.3 and 9.7 per cent for full-time and part-time respectively, while the average rate of job destruction was 3.7 and 6.3 percent. Thus, the average rates of JC\&D for part-time were much greater than total rates. This result is evident in both the 1980s and 1990s as well as within each sector for those periods, with exception of the JDR in the T sector.

During the recession, part-time JCRs are much greater than either full-time or total rates, while part-time JDRs fall below their full-time counterparts overall. JDRs and JCRs were higher in the 1990s than 1980s, particularly for part-time rates. The rise in part-time JCRs was less than that of full-time JCRs, while part-time JDRs rose more than full-time.

Full-time JCRs are similar across sectors, while part-time JCRs for $\mathrm{G}$ sector is generally around double that of the other sectors (particularly the $T$ sector and post-recession). Full-rime JDRs for $G$ sector is one-third higher than other sectors, while part-time JDRs for $G$ sector is much greater than other sectors throughout each period.

The recession stands out as a period where all average JDRs rise and JCRs fall. Part-time JCRs recover from the recession to a lesser extent than full-time. Additionally, while full-time JDRs recover, part-time JDRs continue to rise into the 1990s.

\subsection{Cyclical sensitivity of full-time and part-time employment flows}

In this section we use regression analysis to explore the cyclical sensitivity of full-time and part-time job creation and destruction across industry sectors. We are also seeking to test for evidence of cyclical asymmetries. Table 2 reports the All Industries results. Equation (2.1) shows that full-time job creation is positively related to GDP growth but asymmetries are present - it declines more when GDP growth is negative than it rises when GDP growth is positive. The 1991 recession also impacted severely on both full-time and part-time job creation. However, apart from the recession impact, business cycle influences over part-time job creation are not evident. More work is needed to investigate this result. Full-rime job destruction is highly asymmetric and rises sharply when GDP growth is negative. Part-time job destruction is driven by a trend (not reported) and more work is required to understand this result. 
The results from the industry sector breakdown are available in Mitchell et al (2005b). As expected, full-time job creation across all sectors is cyclically sensitive although evidence of significant asymmetry is only found in the $\mathrm{R}$ sector, which was also negatively impacted by the recession. Part-time job creation is less cyclically sensitive in all but the $R$ sector. However the 1991 recession reduced the rate of part-time job creation in goods production. There is clear asymmetry in job destruction in the $G$ and $T$ sectors although in the case of goods production part-time job destruction is lower when GDP growth is negative while full-time job destruction is strongly positive. The goods sector appears to adjust to cyclical slowdown, in part, by substituting part-time jobs for full-time. The 1991 recession worsened job destruction rates for full-time in both the $G$ and $T$ sectors and part-time in $G$.

Table 2: Cyclical sensitivity of full and part-time job creation and destruction, All Industries, 1983:3 to 2001:4

\begin{tabular}{lcccc} 
Variable & $\begin{array}{c}\text { JCR_Total } \\
\text { Full-time }\end{array}$ & $\begin{array}{c}\text { JCR_Total } \\
\text { Part-time }\end{array}$ & $\begin{array}{c}\text { JDR_Total } \\
\text { Full-time }\end{array}$ & $\begin{array}{c}\text { JDR_Total } \\
\text { Part-time }\end{array}$ \\
& $(1)$ & $(2)$ & $(3)$ & $(4)$ \\
\hline GDP growth positive & $0.475(5.32)$ & $0.142(0.51)$ & $0.067(0.51)$ & $0.192(1.01)$ \\
GDP growth negative & $0.606(1.89)$ & $0.927(0.83)$ & $-3.261(4.51)$ & $0.354(0.85)$ \\
1991 Recession & $-0.009(2.22)$ & $-0.036(3.42)$ & $0.020(3.77)$ & $0.008(1.50)$ \\
Adjusted R & & & & \\
Std Err \% Mean Dep Var & 0.568 & 0.351 & 0.646 & 0.580 \\
No of Observations & 29.0 & 26.1 & 31.6 & 34.5 \\
\hline
\end{tabular}

Note: Detrended 3-qtr centred moving average GDP growth is used throughout. 1991 recession took value 1 from ... and zero otherwise, t-statistics in parentheses. Constant and trend terms not reported (full results available from authors).

\section{Policy application: Work Choices}

These research findings can be considered in the context of the Federal Government's Work Choices legislation. During the years of the Hawke-Keating governments a growing frustration with what had been achieved under the various Structural Efficiency Principles saw a move towards Enterprise Bargaining. Both the then Prime Minister, Paul Keating, and the Secretary of the ACTU, Bill Kelty, believed that Enterprise Bargaining, backed up by a strengthened and well-resourced trade union movement, would do more to promote horizontal and vertical multi-skilling, team-based production, competency-based training, and payment for skills acquired on- and off-the-job. Instead, it laid the foundations for what, under the Howard government was to become an unprecedented expansion of managerial prerogative, which, at the enterprise level, has promoted cost-cutting, race-to-the-bottom strategies. While this new-found flexibility may have facilitated the entry of more women into the labour force, it also coincided with the loss of many highly-skilled full-time positions in manufacturing. Moreover, indexes of under-employment that are regularly published by CofFEE reveal that under-employment has accompanied this growth in part-time and casual employment. 
Under the Work Choices legislation the individually based contracts, which were enabled through Australian Workplace Agreements, will no doubt proliferate. At the same time, in the interests of global competitiveness, the Fair Pay Commission will no doubt allow minimum wage rates to move closer to the lower levels of remuneration provided to workers in less developed nations. At the top-end of the wages scale, however, educated professionals face also an increasingly global labour market. In this case firms have to coax workers from rival firms that operate in metropolitan regions such as London, New York, and Tokyo, where levels of remuneration are high. The inevitable result will be a dramatic widening of wage differentials. This move away from a more traditional and solidaristic wages policy may allow a higher proportion of low-skilled and low-paid workers to 'ride on the coat-tails' of growth in the more privileged traded-goods and services sectors. However, the down side will be that these workers will increasingly become trapped in more precarious and low paid jobs that afford litrle opportunity for career development and training. While greater flexibility will be provided to employers, the burgeoning literature on segmented labour markets suggests that low-skilled workers will be forced to meet demands for numerical flexibility (that is, through varying shift arrangements, working hours, and volatility in the duration employment), while more highly-skilled workers who possess grearer security of employment, will be required to meet a very different set of demands for functional flexibility (that is, through horizontal and vertical forms of multi-skilling job rotation, and even job enrichment).

Under the solidaristic wages policies of the past it was anticipated that all workers would benefit from functional forms of flexibility. Arguably, the current tendency towards concentration of innovarive activity amongst an elite group of symbolic analysts will also impede the more collaborative and wide-ranging forms of continuous improvement and new product development characterising advanced but non- Anglo-Saxon nations. Adverse long-term consequences for Australia, both in terms of welfare and productivity growth, can readily be conjectured, but it will take some time to gather sufficient evidence one way or another.

\section{Conclusion}

This paper, motivated by the differential behaviour of part- and full-time employment over the business cycle, constructed sectoral patterns of job creation and destruction that distinguish status of employment. Full-time job creation is positively related to GDP growth but asymmetries are present - it declines more when GDP growth is negative than it rises when GDP growth is positive. In the case of goods production, part-time job destruction is lower when GDP growth is negative. Full-time job destruction is highly asymmetric and rises sharply when GDP growth is negative, especially in the Goods and Trades sectors. Part-time job creation is less volatile. Mitchell et al. (2005b) also show that the persistence of job creation was relatively high in the 1980s, fell dramatically around the recession and only slightly recovered in the 1990s. In contrast, job destruction persistence rose strongly during the recession, especially in the Goods sector. The persistence of part-ime job creation is higher than persistence of full-time job creation across the full sample, although this gap reduces in the 1990)s growth period for goods and trade service sectors. The persistence of full-time job destruction is generally higher than that for part-time. 
The policy implications of these cyclical sensitivities are straightforward. What is lost through net job loss during the downturn takes much longer to recover from in the upturn. Moreover, recessions appear to leave a residue of underemployment, largely through their differential influence over the composition of part-time and full-time employment.

A question for future research is why part-time employment is less sensitive to recessions. This outcome could reflect the fact that firms are reluctant to sack workers who have received training during temporary downturns. As firms typically invest more in full-time than in part-time workers, an alternative to termination would be to change full-time contracts into part-time contracts ones. One way to test this could be to include a regression variable capturing sectoral levels of training. However, data limitations may restrict this line of enquiry.

\section{Acknowledgements}

This project is supported by ARC Discovery Project DP0449654. The authors thank the anonymous referees and participants at the 7th Path to Full Employment Conference and the 12 th National Conference on Unemployment for useful comments. All errors remain ours.

\section{References}

Borland, J. (1996) 'Job Creation and Job Destruction in Manufacturing Industry in Australia', The Economic Record, 72(216) March, 46-62.

Blanchard, O. and Diamond, P. (1990) 'The Cyclical Behaviour of the Gross Flows of U.S. Workers', Brookings Papers on Economic Activity, 2, 85-155.

Blanchflower, D.G. and Burgess, S.M. (1996) 'Job Creation and Job Destruction in Great Britain in the 1980', Industrial and Labour Relations Review, 50(1), 17-38.

Borland, J., Gregory, B. and Sheehan, P. (2001) Work rich, work poor: inequality and economic change in Australia, Centre for Strategic Economic Studies, Victoria University, Melbourne.

Davis, S., and Haltiwanger, J. (1990) 'Gross Job Creation and Destruction: Microeconomic Evidence and Macroeconomic Implications', NBER Macroeconomics Annual, 128-86.

Davis, S., and Haltiwanger, J. (1992) 'Gross job creation, gross job destruction and employment reallocation', Quarterly Journal of Economics, 107, 819-63.

Davis, S., Haltiwanger, J. and Schuh, S. (1996) Job Creation and Destruction, MIT Press, Cambridge, Massachusetts.

Debelle G. and Swann T. (1998) 'Stylised facts of the Australian Labour Market', Research Discussion Paper, Reserve Bank of Australia.

Konings, J. (1995) 'Job Creation and Job Destruction in the U.K. Manufacturing Sector', Oxford Bulletin of Economics and Statistics, 57, 5-24.

Mitchell, W.F. (2001) 'The unemployed cannot search for jobs that are not there!', in Mitchell, W.F. and Carlson, E. (eds.) Unemployment: the tip of the iceberg, CAER/ UNSW Press: Sydney, 85-117. 
Mitchell, W.F., Muysken, J. and Welters, R. (2005a) 'Search behaviour and the casualties of the (dual) labour market', Working Paper 05-15, Centre of Full Employment and Equity, University of Newcastle.

Mitchell, W.F., Myers, J. and Juniper, J. (2005b) 'The dynamics of job creation and job destruction in Australia', in Wrightson, G. (ed.), Creating a Culture of Full Employment, Proceedings of the 7th Path to Full Employment Conference/12th National Conference on Unemployment, December, 284-306.

Mumford, K. and Smith, P. (2003) 'Job Reallocation, Employment Change and Average Tenure: Theory and Workplace Evidence from Australia', Scottish Journal of Political Economy, forthcoming.

Perry, G. (1990) 'Comments', in Blanchard, O. and Diamond, P. (1990) 'The Cyclical Behavior of the Gross Flows of U.S. Workers, Brookings Papers on Economic Activity, 2, 153.

Ritter, J.A. (1993) 'Measuring Labor Market Dynamics: Gross Flows of Workers and Jobs', Federal Reserve Bank of St. Louis, November/December.

Ritter, J.A. (1994) 'Job Creation and Destruction: The Dominance of Manufacturing', Federal Reserve Bank of St. Louis, September/October.

Song, L. and Webster E. (2003) 'How segmented are skilled and unskilled labour markets: the Case of Beveridge Curves', Australian Economic Papers, 42 , September, 332. 
Copyright of Australian Journal of Social Issues is the property of Australian Council of Social Service and its content may not be copied or emailed to multiple sites or posted to a listserv without the copyright holder's express written permission. However, users may print, download, or email articles for individual use. 